\title{
Interesting Factors of Prospective Teachers
}

\author{
Dr.D.Ponmozhi, \\ Principal, O.P.R.Memorial College of Education,Vadalur,Tamilnadu, India.
}

\begin{abstract}
The present investigation has been undertaken in order to study the Teaching interest of student teacher in Tamil Nadu state. By using the random sampling technique 622 student teachers were selected from various education colleges in Tamil Nadu state. Normative survey method was used. Teaching interest scale constructed and validated by the researcher, (2014) was used to collect the data. A stepwise regression was used to find factors contributing interest of student teachers. Among the 46 factors 18 were found in the $18^{\text {th }}$ step. The model was statistically significant and accounted for approximately $56 \%$ of the variance of teaching interest. Inspection of the structure coefficient suggests that Easy permanent job, opportunity to Share knowledge were relatively strong indicators of teaching interest
\end{abstract}

Keywords: Teaching Interest, Student Teachers

\section{INTRODUCTION}

Global environment creates way for many professionals. The teacher education also has specialized in many new fields and updated itself with innovations. This profession requires multitalented personalities to meet the developmental needs of the learners. Only few percentages of the graduates are preferred to be a teacher and willing to undergo tough training courses. To develop human recourses of our nation we need not only qualified teachers and also interested teachers. Only interested teachers can make their profession more effective and proficient.

\section{NEED OF THE STUDY}

Teaching profession also exposed to lot of challenges like technological advancements, global market, self financed schools and professionalism. To make the survival in this challenging environment can be enhanced by student teachers interest in their profession. This profession has to attract new aspirants to face the $21^{\text {st }}$ century challenges. The researcher wants to find the attracting factors of this profession for the prospective teachers.

\section{Objectives of the study}

1. To find the most interesting element of teaching profession for the prospective student teacher.

2. To find the strength of attracting factor of teaching profession for the prospective student teacher.

\section{Hypothesis of the study}

1. There is no significant interesting element of teaching profession for the prospective student teacher.

2. There is no significant strong attracting factor of teaching profession for the prospective student teacher.

\section{MATERIALS AND METHODS}

With the help of random sampling technique 622 student teachers were selected as samples for the study. Teaching Interest Scale was constructed and standardized by the researchers has been utilized to collect the data from the sample. Stepwise Regression analysis was done with the help of IBM SPSS19 to find the interesting factors of teaching profession.

\section{ANALYSIS AND INTERPRETATION}

Regression analysis was done with the help of IBM SPSS19 to narrow down the most interesting factors of teaching profession for the student teachers. Forty six factors were considered as interesting factors for student teachers. Eighteen factors were identified as significant interesting factors for them as in table-1

Table 1 shows 46 variables and total teaching interest were used in a stepwise multiple regression analysis to predict teaching interest. The correlation of variables and teaching interest were statistically significant. The prediction model contained eighteen of the forty six predictors and was reached in eighteen steps with 28 variables removed. 
The model was statistically significant, $F(\mathbf{1 8 , 5 9 9})=\mathbf{4 2 . 7 9 1 ,} p<.001$, and accounted for approximately $56 \%$ of the variance of teaching interest $\left(\mathrm{R}^{2}=0.563\right.$, Adjusted $\left.\mathrm{R}^{2}=0.549\right)$. Teaching interest is primarily predicted by the lower levels of inspiration given by friends, Initial pay, Nobel Profession, Comfortableness, working with villagers, gratitude received, trusted by the Society and to the lesser extent by the higher levels of opportunity to share Knowledge, Relationship with local people, job nearby house, Quality of Life, Part of cultural activities, and exposed to new technology. The raw and standardized regression coefficient of predictors together with their correlation with teaching interest, their squared semi-partial correlations, and their structure coefficients are shown in table-1.

\begin{tabular}{|c|c|c|c|c|c|c|c|}
\hline \multicolumn{8}{|c|}{$\begin{array}{l}\text { Table-1 STEPWISE REGRESSION BETWEEN TEACHING INTEREST TOTAL SCORE AND } \\
\text { OTHER VARIABLES }\end{array}$} \\
\hline & & b & SE-b & beta & Pearson $r$ & $\mathrm{Sr}^{2}$ & $\begin{array}{l}\text { Structural } \\
\text { coefficient }\end{array}$ \\
\hline & (Constant) & -45.371 & 9.162 & & & & \\
\hline 1 & Share knowledge* & 7.645 & 1.261 & .194 & .398 & 0.027 & 0.530 \\
\hline 2 & Easy permanent job* & .914 & .078 & .316 & .332 & 0.099 & 0.443 \\
\hline 3 & Job near house* & 3.761 & .885 & .129 & .363 & 0.013 & 0.484 \\
\hline 4 & Popularity* & 3.786 & .938 & .119 & .309 & 0.012 & 0.412 \\
\hline 5 & Trusted by society* & 2.141 & 1.092 & .063 & .295 & 0.003 & 0.393 \\
\hline 6 & Love working with villagers* & 2.805 & 1.006 & .082 & .265 & 0.006 & 0.353 \\
\hline 7 & Exposed to new technology* & 3.173 & 1.064 & .091 & .356 & 0.007 & 0.475 \\
\hline 8 & Comfortable* & 1.258 & .437 & .081 & .247 & 0.006 & 0.329 \\
\hline 9 & No good initial pay* & 1.913 & .539 & .101 & .226 & 0.009 & 0.301 \\
\hline 10 & Quality of life* & 3.207 & 1.342 & .076 & .360 & 0.004 & 0.480 \\
\hline 11 & Inspired by friends* & 3.052 & .794 & .110 & .152 & 0.011 & 0.203 \\
\hline 12 & Get gratitude* & 3.309 & 1.214 & .087 & .289 & 0.006 & 0.381 \\
\hline 13 & Part of cultural activities* & 2.329 & .962 & .074 & .358 & 0.004 & 0.477 \\
\hline 14 & Balance profession \& family* & 3.362 & 1.247 & .084 & .312 & 0.005 & 0.416 \\
\hline 15 & Relationship with local* & 3.664 & 1.484 & .083 & .370 & 0.005 & 0.493 \\
\hline 16 & Noble profession* & -2.994 & 1.049 & -.091 & .233 & 0.006 & 0.311 \\
\hline 17 & Moral for young* & 3.160 & 1.200 & .084 & .332 & 0.005 & 0.443 \\
\hline 18 & Update my knowledge* & 3.533 & 1.593 & .068 & .312 & 0.004 & 0.416 \\
\hline
\end{tabular}

Note. The dependent variable Teaching Interest. $R^{2}=0.563$, Adjusted $R^{2}=0.549$

$\mathrm{sr}^{2}$ is squared semi-partial correlation. $\quad * p<.05$

The Easy permanent job received the strongest weight in model followed by opportunity to Share knowledge, Job near house, Popularity, Inspired by friends, No good initial pay, Exposed to new technology, Love working with villagers, Comfortable, Get gratitude, Noble profession, Balance profession \& family, Relationship with local, Moral for young, Quality of life, Part of cultural activities, Update my knowledge and Trusted by society. Trusted by society received the lowest weight of the eighteen weights. With the sizeable correlations between the predictors, the unique variance explained by each of the variables indexed by the squared semi-partial correlation was relatively low: The Easy permanent job, opportunity to Share knowledge, Job near house, Popularity, Inspired by friends, No good initial pay, Exposed to new technology, Love working with villagers, Comfortable, Get gratitude, Noble profession, Balance profession \& family, Relationship with local, Moral for young, Quality of life, Part of cultural activities, Update my knowledge and Trusted by society uniquely accounted for approximately $10 \%, 3 \%, 1 \%, 1 \%, 1 \%, 1 \%, 1 \%, 1 \%, 1 \%, 1 \%, 1 \%, 1 \%, 1 \%, 1 \%, 1 \%$, $1 \%, 1 \%$ and $1 \%$ of the teaching interest. 
Inspection of the structure coefficient suggests that Easy permanent job, opportunity to Share knowledge were relatively strong indicators of teaching interest, and Job near house, Popularity, Inspired by friends, No good initial pay, Exposed to new technology, Love working with villagers, Comfortable, Get gratitude, Noble profession, Balance profession \& family, Relationship with local, Moral for young, Quality of life, Part of cultural activities, Update my knowledge and Trusted by society was a moderate indicator of teaching interest.

\section{CONCLUSION}

Getting permanent job easily and opportunity to share knowledge were most attracting factors of student teachers. So the teacher education colleges should develop their students to face teacher Eligibility tests conducted by state and central government. They have to establish placement cell to fulfill as an urgent and immediate need of the students teachers. They can develop Employment portal. The student teachers may be encouraged to share their knowledge through email, whats up, face book, slide share, blog, reflective journals, ebook, e- tutoring, conferences, workshop and Seminars.

\section{REFERENCE}

[1] Bhalerao,R.P., Roy ,S.,\& Varad,G.R., (2011). A study of the correlation between Career Preference Profile and Interest in Teaching of B.Ed. Students. Indian Streams Research Journal, 1(9), 1-4.

[2] Eren, A. (2012). "Prospective teachers' interest in teaching, professional plans about teaching and career choice satisfaction: a relevant framework?," Australian Journal of Education, 56( 3).

[3] Greenberg,R.B., Ziegler,C.H., Borges,N.J., Elam,C.L., Stratton,T.D.,\& Woods,S.(2013). Medical student interest in academic medical careers:a multi-institutional study, Perspective Medical Education, 2:298-316.

[4] Ige,J.O., Toyobo,E.A., \& Oyegoke,D.A.(2011). An Analysis of Urban Secondary School Students' Interest in Teaching Profession in South-Western Nigeria, Global journal of human social science,11(9).

[5] Krishnaveni,R., \& Anitha,J. (2007). "Educators' professional characteristics", Quality Assurance in Education, 15 (2), 149 - 161.

[6] Mangieri,J.N., \& Kemper, R.E. (1984).Factors Related to High School Students' Interest in Teaching as a Profession. Paper presented at the Annual Meeting of the American Association of Colleges for Teacher Education, Texas Christian University, Fort Worth.

[7] Mustafa,Z. \& Salim,H.(2012).Factors Affecting Students' Interest in Learning Islamic Education, Journal of Education and Practice, 3(13).

[8] Pandey,R.(2011).Teaching interest in B.Ed. Trainee teachers of different faculties International Referred Reseach Journal, 2(19).

[9] Parr,K.M(2006). Preservice teachers' interests and pedagogical judgments, Ph.D.Dessertation. Graduate School of the University of Florida.

[10] Rana,P.S.(2013). A Study of Teaching Competence in Pre and Post Training of B.Ed. Trainees in Relation to their Rank Difference in Entrance Test, Educationia Confab,2(2).

[11] Rekha P. Bhalerao,R.P., Roy,S.,\& , Varad,G.R.(2011).A study of the correlation between Career Preference Profile and Interest in Teaching of B.Ed. Students, Indian Streams Research Journal, I(8).

[12] Ornstein, A.C.(1977).Characteristics of the Teaching Profession, Illinois Schools Journal, 56, 4, 12-21.

[13] Sasikala,V.(2012). Dignity and Professional Interest of B.Ed. Teacher Trainees, International Journal of Scientific and Research Publications,2(11).

[14] Schiefele,U., Streblow,L., \& Retelsdorf,J.(2013).Dimensions of teacher interest and their relations to occupational well-being and instructional practices, Journal for Educational Research Online Journal, $5(1)$.

[15] Stuart,V.B.(2000). Reasons for selecting a teaching career and remaining in the profession: a conversation with 10 African American Roanoke city teachers, Ph.D.Dessertation, Virginia Polytechnic Institute and State University.

[16] Syiem,I.(2014). A Study of the Interest in Teaching among Teacher Trainees of Shillong, IOSR Journal Of Humanities And Social Science, 9(5),78-79.

[17] Tartuce,G.,Nuneso,M.,\& Patrícia,A.A.(2010) Secondary school students and the attractiveness of the teaching career in Brazil, Cadernos de Pesquisa , 4(14). 